\title{
Automatic High Accuracy Tie Points Detection in Stereo Images Using Relaxation Method and Gradient Method
}

\author{
坂元光輝 - 内田 修 · 汪 平涛 \\ Mitsuteru SAKAMOTO, Osamu UCHIDA and Pingtao WANG
}

\begin{abstract}
It is necessary for fully automatic relative orientation to realize precise and stable detection of tie points in stereo images. However, usual approaches such as template matching are not applicable to images of different conditions because parameters depend on features of images strongly. In this paper we proposed a series of techniques based on combination of probabilistic relaxation method and gradient method. By our approach, insensibility on setting parameters is achieved in individual methods and as a result total process is more robust. In addition, by examining detected points using relative orientation equation, it is possible to select points that satisfy required accuracy. The validity of proposed technique was verified by experiments using differently conditioned images.
\end{abstract}

\section{1.はじめに}

写真測量作業の自動化に関するテーマの中でも相互 標定処理は比較的，計算機による自動化を行いやすい 項目であり，ステレオペアの画像から対応点を自動抽 出する問題に置き換えて考えることが出来る。実際, 航空写真や衛星写真のような撮影距離に対して比高差 が小さな画像においては，共線条件式等による簡単な 数学モデルの仮定と, 階層的な特徵点の追跡や多段階 のテンプレートマッチング処理等との組み合わせに よって，比較的良好に画像間の対応を求めることが出 来る ${ }^{1), 2)}$ 。しかしながら，近接写真測量のように視差の 影響が大きくなる画像においては，物体の幾何学的位 相の逆転やオクルージョン等の問題により，良好な画 像対応点を抽出することは必ずしも容易ではない3)。 また，テンプレートマッチングでは，対応付けの妥当 性を相互相関係数等の類似度によって判定することが しばしば行われるが，通常その閾值は撮影条件，撮影 対象毎に変更する必要がある。自動処理において，こ

アジア航測株式会社

Research Institute, Asia Air Survey Co., Ltd

「写真測量とリモートセンシング」VOL. 37，NO. 5， 1998
れは大きな問題となる。従って, 相互標定処理の自動 化を行うにあたっては, 対応点の取得処理が種々の撮 影条件に対してロバストな手法であることと，得られ る対応結果の信頼性の高いことが要求される。

画像間の対応付けのアルゴリズムは, テンプレート マッチングと構造マッチングの二つに大別される4)。 テンプレートマッチングは発見的探索手法であること から，画像のテクスチャ一変化が乏しい場合や，オク ルージョンが存在する場合, また探索範囲以上の視差 を持つ対応において，マッチングの迷走が発生すると いう問題がある。通常，幾何学的な拘束条件の設定や， 多段階のマッチングの実施等によってこれらの影響を 軽減させることが試みられるが，本質的には解決しな い。また，撮影シーンに応じてテンプレートサイズの 変更や不適切な対応の除去を目的とした類似度の設定 閾値の変更等が必要となり，様々な撮影対象に対して ロバストな手法とはなりにくい。一方，構造マッチン グの一つとして位置付けられる弛緩法は，特徴間の対 応付けにおいて，局所並列的な反復処理によって対応 付けの矛盾と曖昧さを低減させる処理である4),55。確率 的弛緩法では，特徵が有する対応付けが確率として表 現され，その確率が周辺に存在する特徵との整合性に よって更新されていくため，たとえ初期に小さな確率 しか持たない対応であっても正しい対応付けである場 
合，最終的には高い確率を持つように更新される。ま た，理想的には視差が同程度の位置にある特徵からま とまった対応が得られるため，テンプレートマッチン グのように個々の対応がそれぞれに迷走するといった 状況は生じない。その反面, 配置の類似した特徵が複 数存在する場合，局所的にまとまった点数での誤対応 を生じる場合もある。周辺との整合性を探索に組み入 れるマッチング手法としては, DP マッチング6ももよく 知られており，1次元探索間の整合性を考慮した 2 次 元探索への拡張も試みられている77。しかし, 同手法は 基本的に標定要素が既知のモデルに対して効果的な手 法であり，本研究のように標定要素を決定するために 対応点の算出を行うような処理には適していない。

本研究では，撮影条件，撮影対象の異なる様々なス テレオ画像対から，特に相互標定の自動化を目的とし た安定かつ高精度な対応点の抽出を行えるようにする ために, 確率的弛緩法と動体計測の分野において開発 された勾配法 ${ }^{3), 8)}$ の組み合わせを基本とした一連の処 理プロセスを提案する。確率的弛緩法においては，誤 対応抽出の軽減のために, 援用点の数による制約条件 を設定するという改良を行った。改良後の確率的弛緩 法によって, 対応付けの正解率が飛躍的に向上し, 処 理時間の短縮が図られることを実験によって確認し た。また, 確率的弛緩法の適用結果に対して, 勾配法 による対応点の選定を行うことの効果についても検証 し，有効な結果が得られたことについても報告する。 相互相関係数を CC (Cubic Convolution) 手法によっ て補間することで, 対応点位置をサブピクセル精度で 算出すると共に, 最終的な対応点対の決定では, 相互 標定に用いられる視差方程式に対して, 可変 LQS (Least Quantile of Squares) 手法9)を適用する検定処 理を行うことによって，より高精度な対応点の算出を 行うことを可能とした。本手法によって，指定された 精度を有する対応点のみを抽出することが可能となっ た。これら個別の処理を一連の処理として組み合わせ ることで, 個々の処理パラメータ設定の処理画像に対 する依存度（パラメータの拘束条件）を低くすること が可能となるため, 結果的に撮影状況の異なる画像に 対する高いロバスト性が実現されることになる。提案 手法が，条件の異なる撮影对象に対して安定した手法 となっていることを 6 組の画像を対象とした実験に よって検証し，良好な結果が得られたことを報告する。 本手法では，数学モデルを検定時にのみ参照すること
から, 計算過程でのモデルの修正に伴う対応点位置の 修正を必要としないため, より高速な処理が可能とな る。

\section{2. 提案手法について}

今回提案する処理手法のフローを図 1 に示す。以下, 個々の手法について概説する。
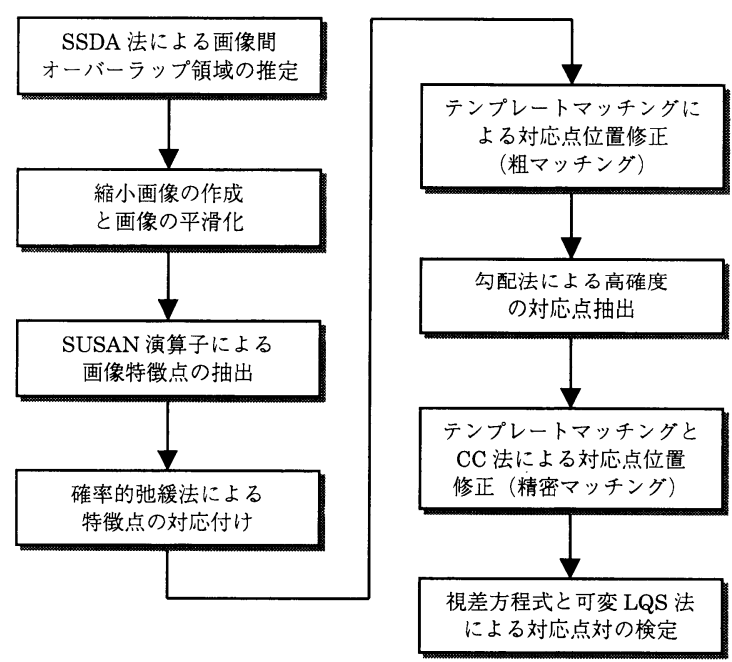

図 1 処理フロー図

\subsection{SSDA 法による画像間オーバーラップ領域の推 定}

ステレオ画像対から大まかなオーバーラップ領域を 抽出するために, SSDA (Sequential Similarity Detection Algorithm）法4),5 による演算結果の平均值 $E$ を 用いた評価を行う。ステレオ画像対におけるそれぞれ の画像を $P, Q$ で表すとき，Eは式（1）で表される。

$E=\frac{1}{n} \sum_{P_{i} \in P_{T}, Q_{i} \in Q_{T}}\left|P_{i}-Q_{i}\right|$

ただし，

$P_{T}, Q_{T}$ : 画像 $P, Q$ を重ねたときのそれぞれの画 像のラップする領域（テンプレート）

$P_{i}, Q_{i}:$ テンプレート $P_{T}, Q_{T}$ を重ねたときの対 応する画素

$n:$ テンプレート内の画素数

$\left|P_{i}-Q_{i}\right|$ の $i$ 番目の点の計算において, $i$ が設定数を 超えたら, 前回までの $E$ の最小值（閾值）との比較を 行い，この值を上回った場合は処理を打ち切ってテン 
プレート領域を移動する。テンプレート全体に渡って

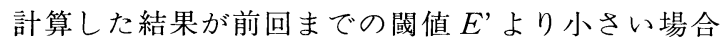
は，これを新たな閾值として設定する。設定した全て のテンプレート領域の計算を終了した時点で, $E$ が最 小となったときのテンプレート領域をオーバーラップ 部分と判定する。大まかなラップ領域を算定すること によって, 確率的弛緩法適用時の対応付けの探索範囲 を狭め，処理時間を短縮することが出来る。実際の計 算においては，処理時間短縮のためにサイズの異なる 様々なシーンの原画像 (表 1 参照) を100画素程度に間 引いて計算させ，実用上の観点から画像全体の $30 \%$ 以 上がラップすると判断される場合にのみ式（1）による 判定を行うこととした。

\section{2 縮小画像の作成と画像の平滑化}

対象とする画像のサイズによって確率的弛緩法等の 処理パラメータをその都度変更することは, 処理の自 動化におけるパラメータチューニング上の観点から望 ましくない。従って, 処理画像に対して式(2)で表さ れるような画像の縮小を行い, 縮小後の画像のサイズ がほぼ500ピクセル程度となるようにした（原画像のサ イズについては表 1 を参照)。

画像の縮小率を $m$, 縮小前の原画像の各画素を $P_{x}$, $y$, 縮小後の画像の各画素を $P_{x, y}^{\prime}$ とするとき,

$m=\min \left\{\left[x_{\text {sizeo }} / x_{\text {size }}\right],\left[y_{\text {sizeo }} / y_{\text {size }}\right]\right\}$

$P_{x, y}^{\prime}=\frac{1}{m^{2}} \sum_{i=0}^{m-1} \sum_{j=0}^{m-1} P_{m x+i, m y+j}$

ただし，

$\min \{\mathrm{i}, \mathrm{j}\}$ ：小さい方の值を返す関数

[i]：i を超えない最大の整数值

$x_{\text {sizeo, }} y_{\text {sizeo }}$ : 原画像のサイズ

$x_{\text {size }}, y_{\text {size }}$ : 縮小後の画像のサイズ

同時に, 次処理の特徵点の抽出精度を高めるために, 画像の平滑化処理を行った。平滑化フィルタとしては, $5 \times 5$ サイズのメディアンフィル夕を使用した。

\subsection{SUSAN 演算子による画像特徴点の抽出}

ステレオ画像対の各々から対応付けの候補となる特 徵点を抽出する。特徵点は画像中の物体のコーナ一等, 出来るだけユニークな点であることが望ましい。本研 究では, コーナー抽出に使用する interest 演算子とし て, Smith 等によって提案された SUSAN (Smallest Univalue Segment Assimilating Nucleus) 演算子10)
を使用した。1 画像あたり1000点前後の特徵点を確保 するために, SUSAN 演算子のパラメータ（画素の輝 度差の設定）を自動調整するようにしている。

\section{4 確率的弛緩法による特徵点の対応付(44),5)}

ステレオ画像対の各々から抽出した特徵点を確率的弛 緩法によって対応付けすることを考える。いま，一方 の画像内のある特徵点 $a_{i}:\left(x_{i}, y_{i}\right)$ がもう一方の画像 の特徵点 $b_{k}:\left(x_{k}, y_{k}\right)$ に対応すると仮定した場合, 特 徵点間の変位べクトル $\lambda_{k}:\left(x_{k}-x_{i}, y_{k}-y_{i}\right)$ をラベル として, 特徵点 $a_{i}$ がラベル $\lambda_{k}$ を持つ確率を $P_{i}\left(\lambda_{k}\right)$ と 定義する。 $a_{i}$ に対応する $b_{k}$ の候補が $L$ 個存在すると き，その候補を $b_{k l}, l=1,2, \cdots L$ ，それぞれのラベルを $\lambda_{k l}, a_{i}$ がどのラベルも持たないときのラベル(空集合) を $\lambda_{m}$ で表すと， $a_{i}$ がこれらのラベル集合に対して持 つラベル確率はそれぞれ $P_{i}\left(\lambda_{k l}\right), P_{i}\left(\lambda_{m}\right)$ と表される。 反復計算によってこれらのラベル確率の増減を繰り返 し，最終的に最も確率の高いラベルを持つ組み合わせ が対応として選択される。

\section{（1）初期のラベル確率}

初期のラベル確率は, 特徵点 $a_{i}$ とその対応点候補 $b_{k l}$ のそれぞれの画像座標位置を中心とする矩形領域 を設定し，矩形領域間の画像の類似度 $S_{i}\left(\lambda_{k l}\right)$ を用い て次式のように定義する。なお，本研究では類似度と して相互相関係数を使用した。

$$
\begin{aligned}
& P_{i}^{(0)}\left(\lambda_{m}\right)=1-\max \left(S_{i}\left(\lambda_{k l}\right)\right) \\
& P_{i}^{(0)^{\prime}}\left(\lambda_{k l}\right)=\frac{S_{i}\left(\lambda_{k l}\right)}{\sum_{l=1}^{L} S_{i}\left(\lambda_{k l}\right)}\left(1-P_{i}^{(0)}\left(\lambda_{m}\right)\right) \\
& l=1,2, \cdots, L
\end{aligned}
$$

\section{（2）ラベル確率の更新}

特徵点 $a_{i}$ が対応点候補 $b_{k l}$ を持つラベル確率は， $a_{i}$ の近傍に存在する特徵点 $a_{j}$ (以後, 援用点と呼ぶ）に よって計算される適合係数 $Q_{i}\left(\lambda_{k l}\right)$ を用いて, 式 $(7)$ のように更新される。

$$
\begin{aligned}
& Q_{i}^{K}\left(\lambda_{k l}\right)=\sum_{j} \sum_{\lambda_{k l} \in\left\{\lambda_{k l}-\lambda_{k l} \mid \leq \theta\right\}} P_{k l^{\prime}}^{K}\left(\lambda_{k l}\right) \\
& P_{i}^{K+1}\left(\lambda_{k l}\right)=\frac{P_{i}^{K}\left(\lambda_{k l}\right) \times\left(A+B \times Q_{i}^{K}\left(\lambda_{k l}\right)\right)}{\sum_{l \in L}\left(P_{i}^{K}\left(\lambda_{k l}\right) \times\left(A+B \times Q_{i}^{K}\left(\lambda_{k l}\right)\right)\right)}
\end{aligned}
$$

$l=1,2, \cdots, L$

ただし,

$$
\begin{aligned}
& K: \text { 処理の反復回数 } \\
& \lambda_{k l^{\prime}}: a_{j} \text { が } b_{k l^{\prime}} \text { に対して持つラベル } \\
& \theta: a_{i} \text { が持つラベル } \lambda_{k l} \text { と } a_{j} \text { が持つラベル } \lambda_{k l^{\prime}}
\end{aligned}
$$


を矛盾しないとみなすときの許容量

$A, B$ : 確率的弛緩法の収束特性を決定する定数

更新後のラベル確率が極端に小さいものは, 值を強 制的に 0 とする。また, ラべル $\lambda_{k l}$ の数が 0 となった特 徵 $a_{i}$ はどの点にも対応しないので, 対応点の候補から 削除する。

\section{（3）確率的弛緩法に対する拘束条件}

本研究では確率的弛緩法に対して, 誤対応付けの軽 減を目的として以下の拘束条件を設定した。

（a）ラベル更新の初期における援用点数による拘 束

設定回数 $K_{m}$ 以内のラベル確率の更新におい て, 援用点数 $n_{\lambda}$ が設定数 $n_{0}$ より少ない場合に適 合係数 $Q_{i}\left(\lambda_{k l}\right)$ の值を 0 とし, 設定回数以降の反復 計算では援用点数による拘束を外す（援用点の設 定数を 0 とする）かまたは弱める（n $n_{0}$ より小さな 值 $n_{0}{ }^{\prime}$ とする)。

$Q_{i}^{K}\left(\lambda_{k l}\right)=0: K<K_{m}$ and $n_{\lambda}<n_{0}\left(K \geq K_{m}\right.$ and $n_{\lambda}$

$$
\left.<n_{0}{ }^{\prime}, n_{0}{ }^{\prime}<n_{0}\right)
$$

$Q_{i}^{K}\left(\lambda_{k l}\right):$ 上記以外

これにより，反復計算の初期の段階で不適切な ラベルを大幅に削減することが可能となる。また， 指定回数以上の反復で拘束条件を弱くすることに よって, 反復回数の増加に伴って, 対応点の数が 著しく減少することを防ぐことが出来る。

（b）援用点を選択する領域の設定

適合係数を計算する際の援用点の選定領域に対 して，式(9)のような拘束を設定する。

$R_{\min } \leq \max \left\{\left|x_{i}-x_{j}\right|,\left|y_{i}-y_{j}\right|\right\} \leq R_{\max }$

ただし,

$\max \{i, j\}$ : 大きい方の值を返す関数

$R_{\min }$ : 近すぎる援用点を選択しないように指 定するサイズパラメータ

$R_{\max }$ : 援用点として選択する最大の領域を指 定するサイズパラメータ

$R_{\min }$ を設定することにより, 近すぎる援用点が 選択されないため, 局所的に極めて類似した配置 を持つ特徵点群の存在による誤った対応付けの可 能性をより小さくすることが出来る。

\section{(4) 収束判定}

次のいずれかの条件を満たした場合に収束したもの と判断する。

（a）ラベル確率に変化がなくなった場合（設定閾 $-38-$
值以内の変動量となったとき)

（b）規定の反復回数に達した場合（その時点で最 も高い確率を持つラベルを選択する)

\section{5 テンプレートマッチングによる対応点位置の修 正（粗マッチング）}

確率的弛緩法によって行われた特徵点間の対応付け は, 各々の画像から独立に取得された特徵点を対象と したものであることから，峳密に対応する位置にある とは限らない。そこで, 前段の処理において使用され たものと同じ縮小画像上でテンプレートマッチング処 理を行うことによって, 縮小画像上におけるピクセル 単位での対応点位置の微小修正（粗マッチング処理） を行う。確率的弛緩法によるマッチングによって，原 理的にオクルージョン部分に相当する地点の対応点は ほほ除去されるため，テンプレートマッチングによる 位置修正によってオクルージョンに起因する迷走は発 生しないと考えられる。

\section{6 勾配法による高確度な対応点抽出}

確率的弛緩法によって得られた対応点の結果（対応 点グループ $G a$ とする)から，より整合性の高い対応点 を絞り込む（絞り込まれた対応点のグループを $G b$ と する）ために，勾配法を適用することを考える。これ は，後段の処理である縦視差検定による対応点の検定 処理において，より確度の高い対応点を検定の標本と することと，標本点の組み合わせの絶対数（検定処理 の試行数) を減らすことを目的とするほか，対応点の 推定法として全く異なる二つの手法を複合的に使用す ることで，対応点算出のロバスト性を高めるために行 うものである。

勾配法は Horn 等によって導出されたオプティカル フロー推定手法の一つであり, 動体の小さな動きの推 定に有効な手法である ${ }^{8)}$ 。勾配法の基本方程式は式 (10)のように表される。

$\frac{\partial E}{\partial x} \frac{\partial x}{\partial t}+\frac{\partial E}{\partial y} \frac{\partial y}{\partial t}+\frac{\partial E}{\partial t}=0$

ただし，

\section{$t:$ 時刻}

$E$ : 時刻 $t$ における画像上の点 $(x, y)$ の明るさ 式(10)を満足するような変位べクトルを算出すること がオプティカルフロー推定であるが, 視差が小さい対 応点を対象とすれば，動体の動きと視差による物体の 
移動とを同一視することにより，確率的弛緩法によっ て算出された変位べクトルを検定することに式(10)を 用いることが出来る。ここで，弛緩法によって算出さ れた変位べクトルを式(10)の左辺に代入した場合, 右 辺が必ずしも 0 とはならないため, ある許容值 $T$ を設 定し, これを満たす変位べクトルを持つ対応は, 勾配 法による推定結果と矛盾しないものと考える。実際の 適用においては, 確率的弛緩法による変位べクトル結 果から, SSDA 法によって推定されたステレオ画像対 間のずれ量分の值を差し引いた変位量をオプティカル フローに相当する移動量であるとみなした。

\section{7 テンプレートマッチングと CC 法による対応点 位置修正（精密マッチング）}

前段までの処理は，画像サイズの違いによるパラ メー夕修正の回避と処理の高速化のために，縮小した 画像を対象として処理を行っている。ここでは, 実サ イズの画像 (原画像) を用いて相互相関係数によるテ ンプレートマッチング (精密マッチング) を実施する。 また, ピクセル単位で算出した相互相関係数值を CC 法によって補間し, 最大のピークを示すサブピクセル 位置を対応点位置として修正する。対応点位置の修正 は, 対応点のグループ $G a, G b$ の両方に対して実施す る。さらに，相互相関係数值が極端に小さな対応をこ の時点で棄却する。

\section{8 視差方程式と可変 LQS 法による対応点対の検定}

視差方程式と可変 LQS 法9)に基づいた縦視差検定 によって, 高精度な対応点対の選定を行うための処理 について述べる。対応点グループ $G a$ には視差の大き な点等, 本来適切な对応点ではあるが, 勾配法を満足 しなかった点対が含まれている。そこで, 確率的弛䋸 法と勾配法の両方を満足する確度の高い対応点グルー プである $G b$ に含まれる対応点をサンプリングして視 差方程式を決定 (標定要素を算出) し, 可変 LQS 法に よってグループ $G a$ 中から最終的に正しい対応点のみ を抽出することを考える。

LQS 法 ${ }^{11)}$ は, $n$ 個のデータの自乗䛊差を小さい順に 並べたとき, $\alpha n(0<\alpha \leqq 1)$ 番目に位置するデー夕の值 が最小となるようなパラメー夕を推定するロバスト推 定手法である。可変 LQS 法はこれを拡張し, 対象とす るデータ列に存在する不適切なデータの割合が未知の 場合に, 検定結果を参照して $\alpha$ を可変とするものであ
る $^{9)}$ 。

いま，対応点グループ $G b$ の中ら設定した点数の 対応点を任意にサンプリングし，これらの点列を用い て, 相互標定で使用される視差方程式（縦視差消去に よる相互標定式) ${ }^{12)}$ を最小二乗法によって解く。視差方 程式の安定した決定には最低 6 組の対応点を選択する 必要があり ${ }^{3)}$ これを 1 試行あたりの標本数とする。本 研究では, 文献 ${ }^{12)}$ の視差方程式を厳密に解いた式を使 用した。計算によって得られた外部標定要素を用いて, 対応点グループ $G a$ に含まれる各点対の縦視差 (誤差) の絶対值 $d_{i j}$ を算出し, 小さい順に並べる $(i$ は試行の 回数, $j$ は点対のデー夕の並びを表す)。各試行の $d_{i j}$ の 組に対してLQS 法に基づいて, 誤差の小さい方から $\alpha n$ 番目のデータが最小となったときの試行 $i$ を選択 し, 試行 $i$ 時の $\alpha n$ 番目の誤差より大きい点対を萧却 する。棄却後に残った全ての点対を使用して, 再度視 差方程式を解く。縦視差の最大值が設定している閾值 を超える場合には， $\alpha$ の值を小さくして処理をやり直 す (可変 LQS 法)。最終的に残った点対を対応点とし て判定し, 標定要素の算出を行う。

\section{3 . 検証実験}

\section{1 実験方法}

提案手法の妥当性を検証するために, 以下の 3 項目 に関する実験を行った。

（1）確率的弛緩法における援用点の拘束条件によ る効果の検証実験

（2）勾配法による対応点選定の効果の検証実験

(3) 提案手法の適用実験

実験に使用した対象画像の特徵を表 1 に示す。また， 実験時に設定した基本的な処理パラメータは表 2 の通 クである。

（1）実験 1 : 確率的弛緩法における援用点の拘束条 件による効果の検証実験

対象画像として近接撮影と航空写真の中間的な撮影 状況にある「造成地」の画像を選び, 本手法で設定し た援用点による拘束条件の有用性を確認するための実 験を行った。次のような状況を考慮した 6 ケースを設 定した。設定したケースを表 3 に示す。

（a）援用点による拘束を有効とする反復回数（有 効反復数）を制限せず，援用点数のみを変化 させた場合（3ケース） 
表 1 実験対象画像の特徵

\begin{tabular}{|c|c|c|c|c|}
\hline 撮影シーン名 & 分類 & $\begin{array}{l}\text { 画像サイズ } \\
\text { (ピクセル) }\end{array}$ & $\begin{array}{l}\text { 画素サイズ } \\
(\mu \mathrm{m})\end{array}$ & 画像の特徵 \\
\hline 室内 & 近接平行撮影（地上写真） & $1280 \times 1000$ & 6.8 & $\begin{array}{l}\text { ・デジタルカメラ画像 } \\
\text { ・視差の影響大 }\end{array}$ \\
\hline 交差点 & 近接平行撮影（地上写真） & $1280 \times 1000$ & 6.8 & $\begin{array}{l}\text { ・デジタルカメラ画像 } \\
\text { ・構造物に類似パターンが多数出現 }\end{array}$ \\
\hline 遺構跡 & 近接平行撮影（地上写真） & $2036 \times 3060$ & 9.0 & $\begin{array}{l}・ \text { ・゙ジタルカメラ画像 } \\
\text { ・影の映り込みの影響大 }\end{array}$ \\
\hline 造成地 & 近接平行撮影（地上写真） & $1280 \times 1000$ & 6.8 & $\begin{array}{l}\text { ・デジタルカメラ画像 } \\
\text { ・テクスチャの変化小 }\end{array}$ \\
\hline 市街地A & 直下視撮影（航空写真） & $5409 \times 5436$ & 42.3 & $\begin{array}{l}\text { ·航空写真の } \mathrm{A} / \mathrm{D} \text { 変換画像 } \\
\text { ・テクスチャの変化大 }\end{array}$ \\
\hline 市街地 B & 収斂撮影（航空写真） & $2048 \times 2048$ & 9.0 & $\begin{array}{l}\text { ·撮影角 } \pm 30^{\circ} \text { (衛星) をシミュレート } \\
\text { ・テクスチャの変化大 }\end{array}$ \\
\hline
\end{tabular}

表 2 主要な処理パラメータ

\begin{tabular}{|c|c|c|c|}
\hline 処理パラメー夕項目 & 設定值 & 処理パラメー夕項目 & 設定值 \\
\hline 縮小画像サイズ & 500 & 収束判定用ラベル確率変動量 & $1.0 \times 10^{-5}$ \\
\hline 画像特徵点取得点数 & 1000 & 拘束援用点数（設定反復回数以内） & 4 \\
\hline 対応点対候補探索サイズ & $60( \pm 30)$ & 拘束援用点数（設定反復回数以降） & 2 \\
\hline 類似度計算時の矩形領域サイズ & 15 & 援用点の拘束が有効な反復回数 & 10 \\
\hline ラベルの矛盾を許容するずれ量 & 1 & 勾配法適用時の局所領域サイズ & 11 \\
\hline 援用点取得領域サイズ（最大値） & $100( \pm 50)$ & 勾配法による演算結果の許容值 & 20 \\
\hline 援用点取得領域サイズ（最小値） & $20( \pm 10)$ & 精密マッチング時の相関係数間値 & 0.3 \\
\hline 弛緩法の最大反復回数 & 100 & 視差方程式計算時の対応点標本数 & 6 \\
\hline 弛緩法収束特性決定パラメータ A & 0.5 & 縦視差検定の各 $\alpha$ における試行数 & 1000 \\
\hline 弛緩法収束特性決定パラメータ B & 5.0 & 縦視差精度設定閾值（ピクセル数） & 0.2 \\
\hline
\end{tabular}

表 3 確率的弛緩法に対して設定された拘束条件の異なる 実験ケース

\begin{tabular}{c|ccc}
\hline \multirow{2}{*}{ ケース } & \multicolumn{3}{|c}{ 拘束条件 } \\
\cline { 2 - 4 } & $\begin{array}{c}\text { 援用点数 } \\
\text { (有効反復数内) }\end{array}$ & $\begin{array}{c}\text { 援用点数 } \\
\text { (有効反復数以降) }\end{array}$ & $\begin{array}{c}\text { 援用点有効 } \\
\text { 反復数 }\end{array}$ \\
\hline (a ) -1 & 0 & 0 & 制限なし \\
(a) -2 & 4 & 4 & 制限なし \\
(a) -3 & 8 & 8 & 制限なし \\
(b) -1 & 6 & 0 & 10 \\
(b) -2 & 6 & 0 & 50 \\
(c) -1 & 6 & 4 & 10 \\
\hline
\end{tabular}

（b）援用点数を固定して，有効反復数のみを変化 させた場合（2ケース）

(c) 有効反復数を固定して, 有効反復数以降の援 用点の拘束点数を少なくした場合（１ケース） なお, 対応の妥当性の判断は, 対応点を 1 組ずつ画 $-40-$
面に拡大表示させ，対応点位置の目視によるチェック によって行った(以下の実験でも同様)。また, 確率的 弛緩法によるマッチングは特徵間の対応付けであり， 位置の修正がなされていないので, 明らかに対応が間 違っているものを誤対応として判断した。

\section{（2）実験 2 ：勾配法による対応点選定の効果の検証 実験}

確率的弛緩法によって得られた対応点算出結果に対 して, 勾配法を適用した場合の対応点選定の効果を確 認するために，次の二つのケースに対する検証実験を 行った。

（a）援用点の拘束条件を設定しない確率的弛緩法 による対応点算出結果に適用した場合

（b）援用点の拘束条件を設定した確率的弛緩法に よる対応点算出結果に適用した場合

確率的弛緩法による算出対応点の変位ベクトル量を 式(10)に代大したときに，勾配法との矛盾を許容する 
許容値 $T(2.6$ を参照 $)$ をパラメータとした場合の対応 点の選定結果を比較する。「室内」の画像を対象とし， ケース（b)では援用点に関する拘束条件を表 2 に掲載 のものよりやや弱め, 故意に䛊対応を増やすことで, 公配法による効果を確認することとした。

\section{(3) 実験 3 : 提案手法の適用実験}

提案手法を撮影状況抢よび撮影対象の異なる様々な シーンに対して適用することによって，提案手法の有 効性を確認した。その際, 処理パラメータは全ての画 像で同一のもの（表2）を使用した。これによって, パラメータの処理画像への依存度の低さを実証するこ とが出来る。また, 取得可能な対応点数を増やすため, 確率的弛緩法に対する援用点についての拘束条件は弱 めに設定した。なお，弛緩法終了時点での対応点につ いては位置の修正が行われていないので, 対応が明ら かに矛盾する点を誤対応であると判断した。

\section{2 実験結果}

\section{(1) 実 験 1}

確率的弛緩法に設定した援用点に関する拘束条件を 変えた場合の各ケース毎の対応点正解率を表 4 に示 す。拘束条件を全く設定しないケース ( a ) - 1 , 最も拘 束の強いケース $(\mathrm{a})-3$ ，それらの中間的な条件である ケース $(\mathrm{c})-1$ の反復回数に対する対応点の候補が有 するラベル数の推移を図 2 に示す。

\section{(2) 実 験 2}

確率的弛緩法に対する拘束条件の有無によって設定 された二つのケースにおける勾配法許容值 $T$ に対す る対応点の正解率と対応点数の関係をそれぞれ図 3 , 図 4 に示す。

\section{(3) 実 験 3}

SSDA 法によって推定された対象シーン毎のオー バーラップ率と特徵点抽出処理によって取得された特

表 4 確率的弛緩法に対する拘束条件の違いによる 対応の正解率

\begin{tabular}{c|cc}
\hline ケース & 誤対応数/対応数 & 対応正解率 (\%) \\
\hline (a) -1 & $38 / 239$ & 84.1 \\
(a) -2 & $2 / 145$ & 98.6 \\
(a) -3 & $0 / 63$ & 100.0 \\
(b ) -1 & $5 / 185$ & 97.3 \\
(b) -2 & $0 / 103$ & 100.0 \\
(c) -1 & $0 / 139$ & 100.0 \\
\hline
\end{tabular}

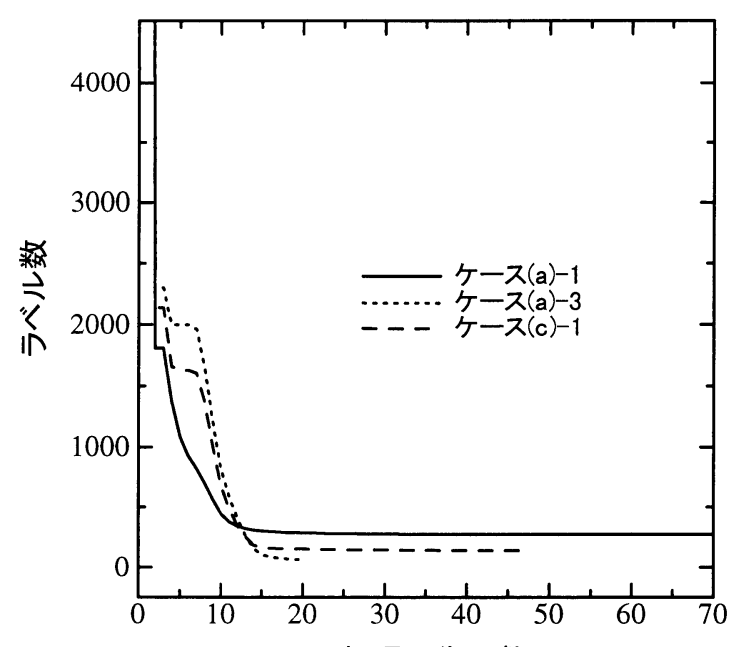

処理反復回数

図2 確率的弛緩法の拘束条件が異なるケースの反復回数 とラベル数の関係



許容值T

図 3 勾配法許容値 $T$ に対する対応点数と正解率の推移 （拘束条件なし）

徵点数を表 5 に示す。また, 各処理の終了段階での誤 対応点数と最終正解率, 推定された標定要素による残 存縦視差の RMSE（Root Mean Square Error）結果 を表 6 に示す。最終的に選択された対応点画像を図 5 ～図10に示す。

\section{（4）処理時間}

処理時間は画像サイズやオーバーラップ部分の割 合, 取得可能な対応点数の違い等によって多少変動す るものの, パソコン環境 (CPU : Pentium II $300 \mathrm{MHz}$ ，メモリ：96MB）で概ね60秒程度であった。 


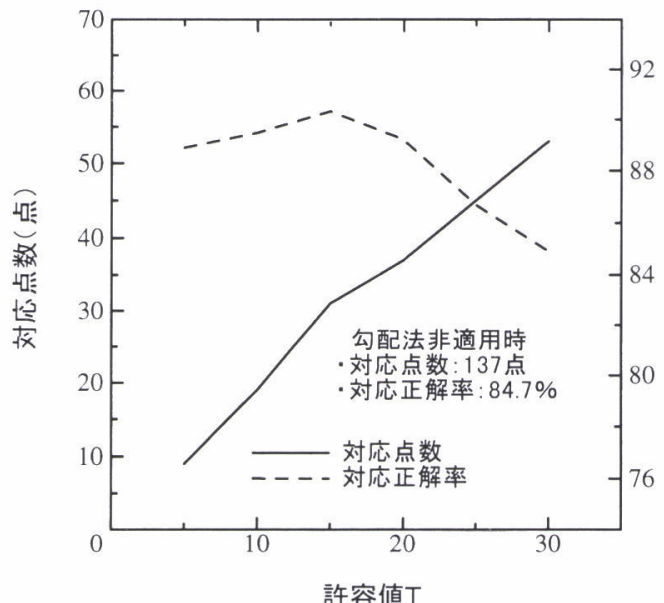

図 4 勾配法許容值 $T$ に対する対応点数と正解率の推移 (拘束条件あり)
表 5 対象シーンのオーバーラップ率と抽出された特徵点 数

\begin{tabular}{|c|c|c|c|}
\hline \multirow{2}{*}{ 撖影シーン名 } & \multirow{2}{*}{$\begin{array}{c}\text { オーバーラップ讋 } \\
(\%)\end{array}$} & \multicolumn{2}{|c|}{ 初期特徵点数 (点) } \\
\hline & & 左画像 & 右画像 \\
\hline 至内 & 72 & 1018 & 1088 \\
\hline 交差点 & 81 & 1078 & 973 \\
\hline 遺構跡 & 74 & 1194 & 1238 \\
\hline 造成地 & 91 & 1034 & 1084 \\
\hline 市街地A & 60 & 1185 & 1246 \\
\hline 市街地B & 100 & 1153 & 1226 \\
\hline
\end{tabular}

表 6 各処理段階の終了時における誤対応点数の推移と最終正解率

\begin{tabular}{|c|c|c|c|c|c|c|}
\hline 撮影シーン名 & $\begin{array}{c}\text { 確摔的弛緩法 } \\
\text { (点数) }\end{array}$ & $\begin{array}{l}\text { 勾配法 } \\
\text { (点数) }\end{array}$ & $\begin{array}{c}\text { 縦視差検定 } \\
\text { (点数) }\end{array}$ & $\begin{array}{c}\text { 最終正:解悴 } \\
(\%)\end{array}$ & $\begin{array}{c}\text { 縦視差最大值 } \\
(\mu \mathrm{m})\end{array}$ & $\begin{array}{c}\text { 縦視差 RMSE } \\
(\mu \mathrm{m})\end{array}$ \\
\hline 窒内 & $16 / 106$ & $2 / 35$ & $0 / 29$ & 100.0 & $1.18 \quad(6.8)$ & $0.66 \quad(6.8)$ \\
\hline 交差点 & $33 / 148$ & $6 / 62$ & $0 / 39$ & 100.0 & $1.05 \quad(6.8)$ & $0.60 \quad(6.8)$ \\
\hline 遺構跡 & $3 / 188$ & $0 / 102$ & $0 / 74$ & 100.0 & $1.61(9.0)$ & $0.74 \quad(9.0)$ \\
\hline 造成地 & $6 / 190$ & $3 / 153$ & $0 / 111$ & 100.0 & $1.04(6.8)$ & $0.50 \quad(6.8)$ \\
\hline 市街地 A & $4 / 149$ & $0 / 81$ & $0 / 59$ & 100.0 & $7.81 \quad(42.3)$ & $3.77(42.3)$ \\
\hline 市街地B & $11 / 367$ & $4 / 319$ & $0 / 107$ & 100.0 & $1.58(9.0)$ & $0.80 \quad(9.0)$ \\
\hline
\end{tabular}

（注 1) 表記「X/Y」は，各処理の終了時に扔ける「䛊対応点数/対応点数」を表す。

(注2）（）内の数值は 1 ピクセル（1 CCD あたり）の汇素サイズを表す。

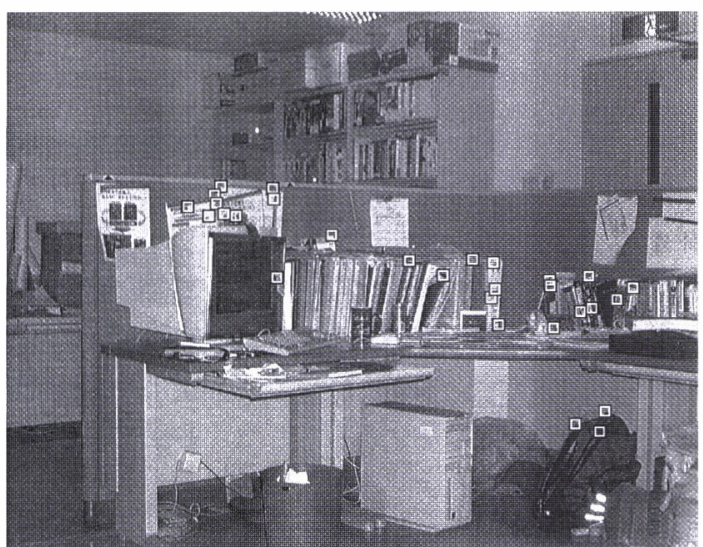

(a) 左画像

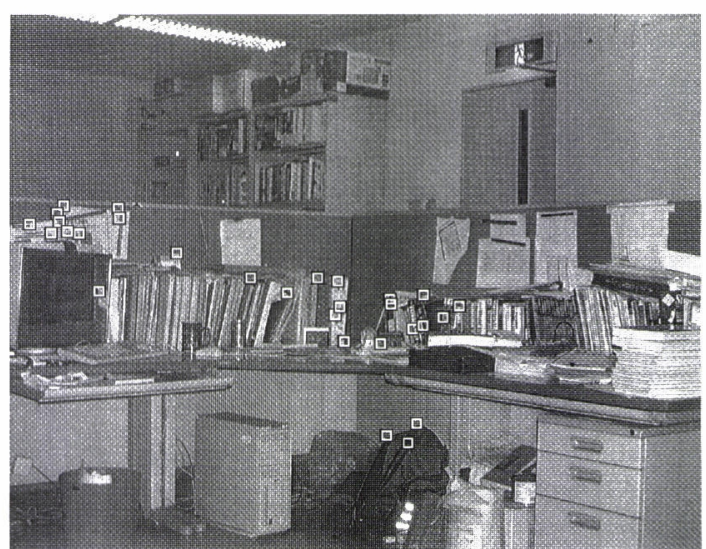

(b) 右画像

図 5 対応点抽出結果：室内 


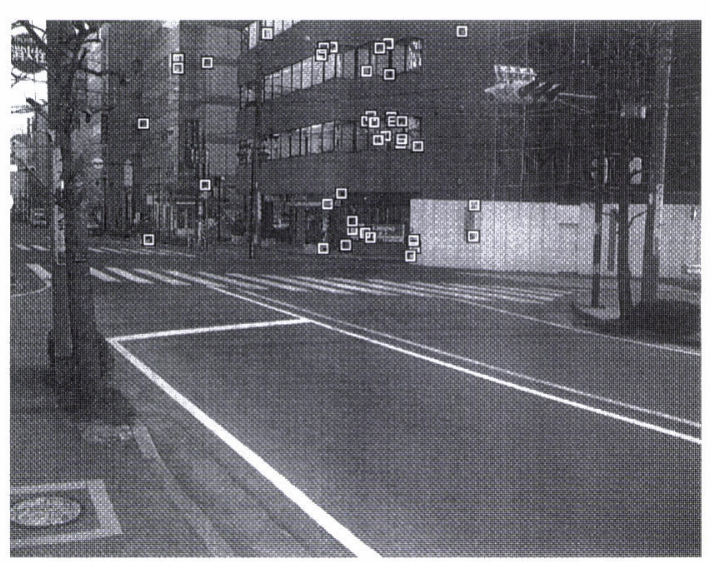

(a) 左画像

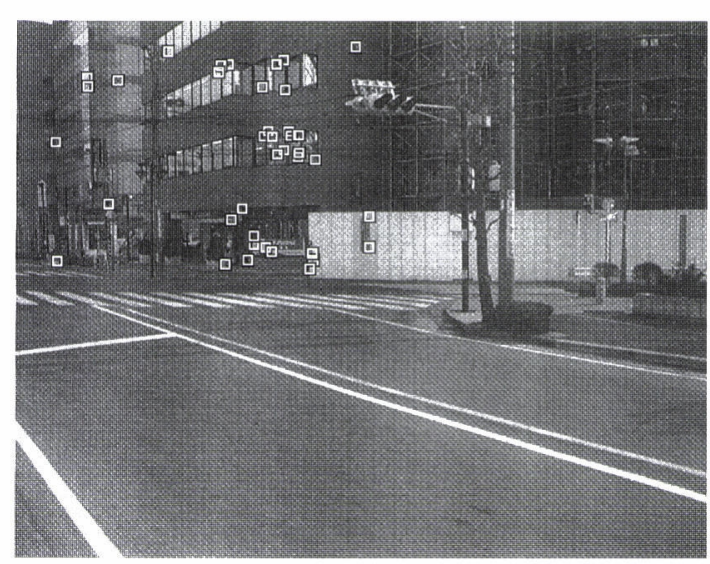

(b) 右画像

図 6 対応点抽出結果：交差点

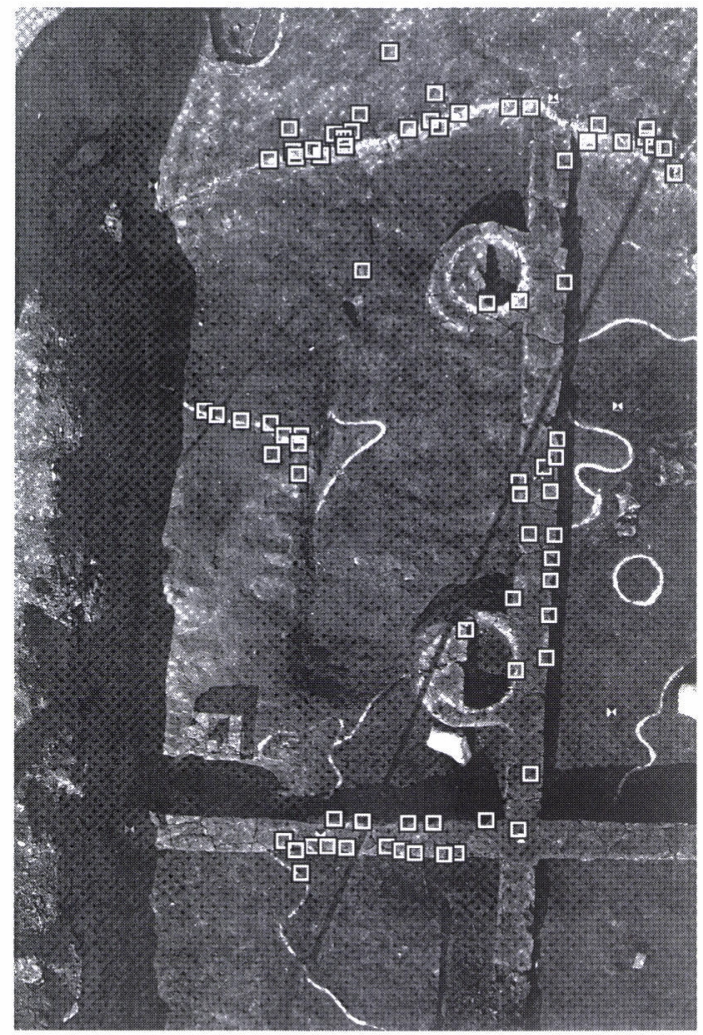

(a) 左画像

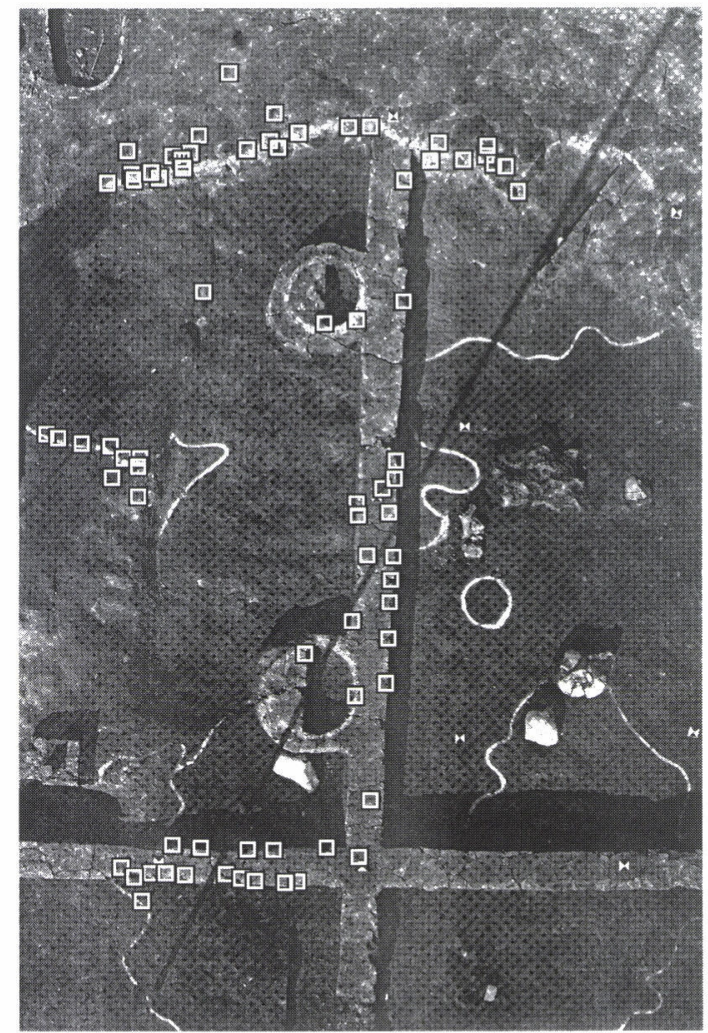

(b) 有西像

図 7 対応点抽出結果：遺構跡 


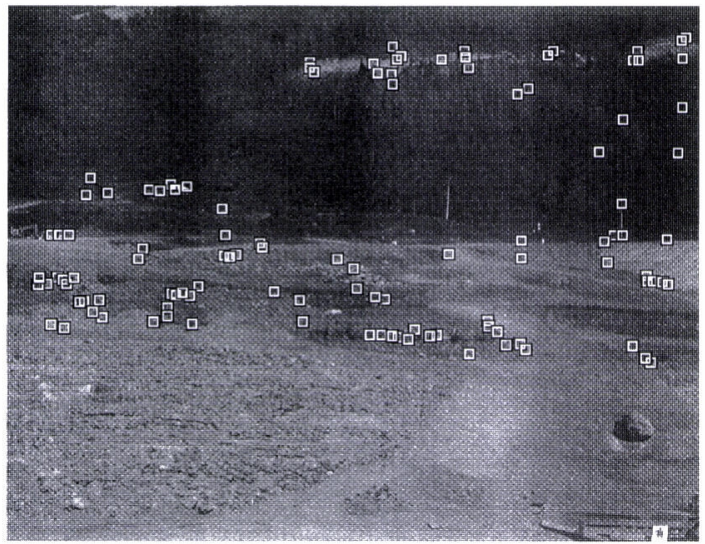

(a) 左画像

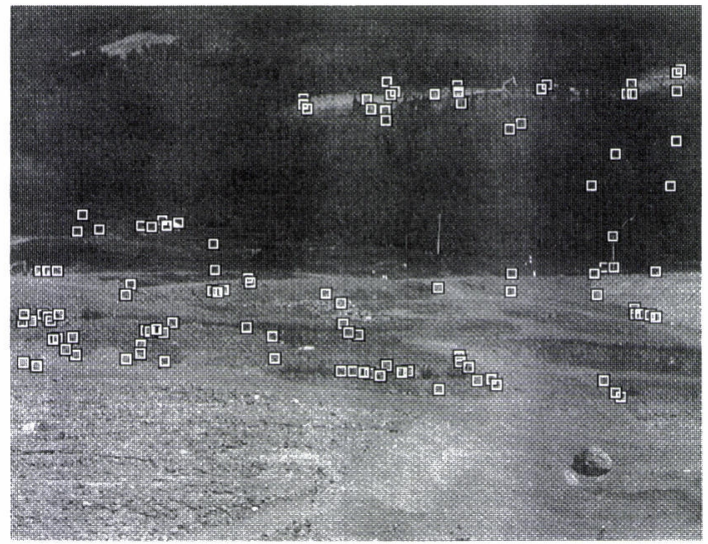

(b) 右画像

図 8 対応点抽出結果：造成地

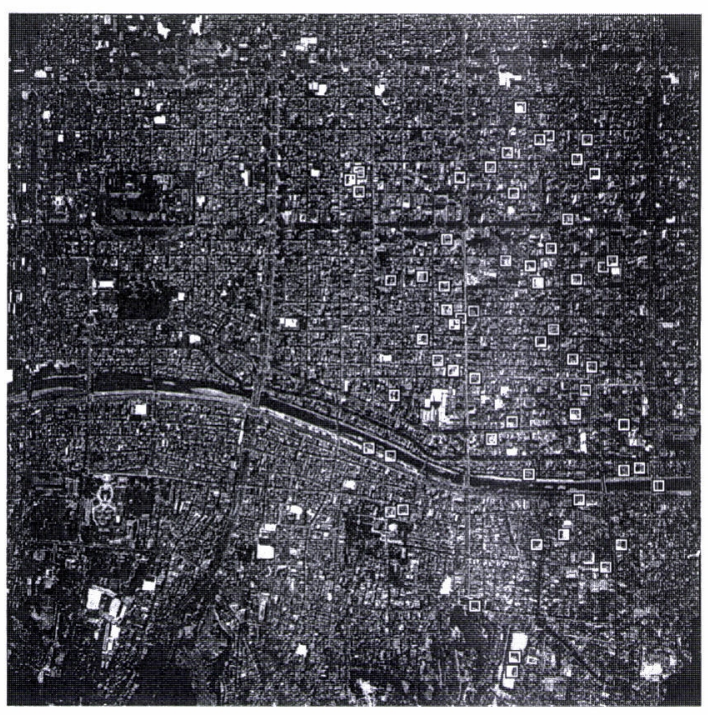

(a) 左画像

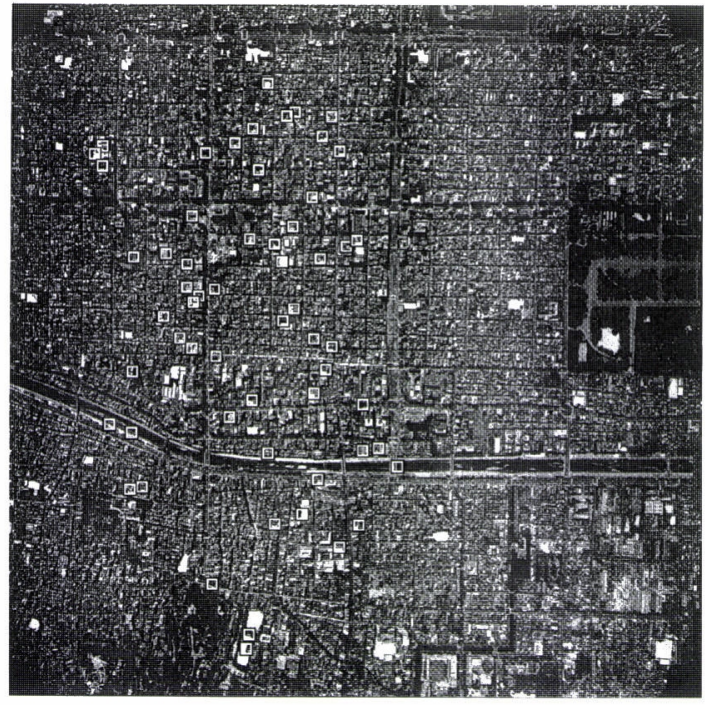

(b) 右画像

図 9 対応点抽出結果：市街地 A

処理レベル毎の概略的な処理時間を表 7 に示す。

\section{3 実験結果の考察}

（1）確率的弛緩法に対する拘束条件の設定について 表 4 より確率的弛緩法において, 提案手法の一つで ある援用点による拘束を強めるほど，拘束条件を設定 しない場合と比較して対応付けの精度が飛躍的に向上 することが確認された。四 2 の結果から拘束条件を強 くすると, ラベルの削除される速度が反復処理の初期 では緩やかであるが次第に早くなり，処理の収束に要
する反復回数が少なくなることが分かる。一方，収束 時のラベル数は対応点数に相当するが, 図より拘束を 強めるほど取得可能な対応点数が減少する様子も確認 出来る。

\section{（2）勾配法の効果について}

网 3, 図 4 の結果加確率的弛緩法によって算出し た対応点の中から勾配法を利用して対忍点の選別を行 うと, 許㢲值を小さくするに従って対応付けの正解率 が上开する傾问にあることが確認された。許容值が小 さくなっても正解率が滅少する筒所も存在するもの 


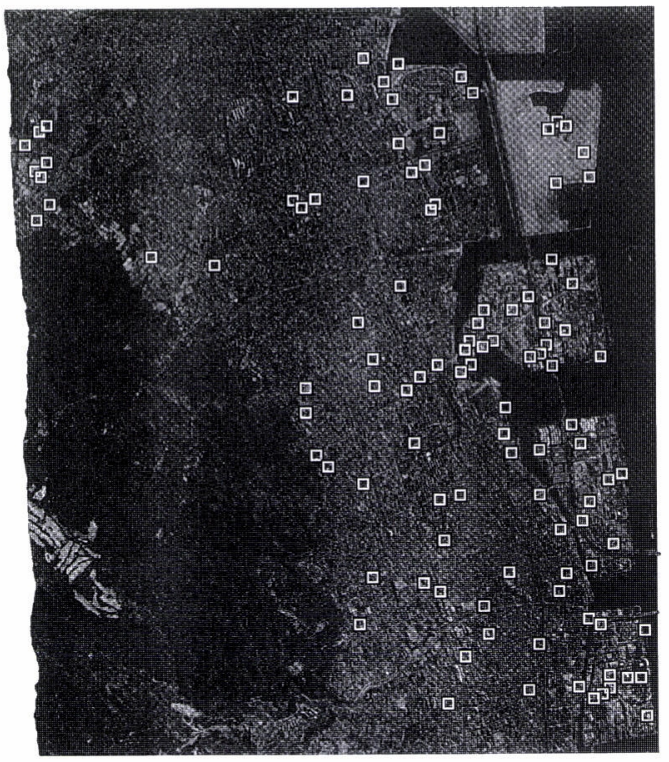

(a) 左画像



(b) 右画像

図10 対応点抽出結果：市街地B

表 7 概算処理時間

\begin{tabular}{l|c}
\hline \multicolumn{1}{c|}{ 処理項目 } & 処理時間 (sec) \\
\hline 画像オーバーラップ領域算出 & $1 \sim 2$ \\
縮小画像作成（原画像サイズにより変動） & $1 \sim 20$ (2画像分) \\
画像平滑化 & 1 (2画像分) \\
画像特徵点抽出（閾值自動決定により変動) & $1 \sim 4$ \\
確率的弛緩法 (収束回数により変動) & $10 \sim 25$ \\
粗マッチング & 1 \\
勾配法によるチェック & 1 \\
精密マッチング (対応点数により変動) & $1 \sim 5$ \\
縦視差検定（算出対忘点精度により変動) & $2 \sim 20$ \\
\hline
\end{tabular}

の，対応の正解率自体は手法の適用前よりも上昇して いることが分かる。すなわち, 勾配法の適用は確度の 高い対応点の絞り込みに効果があると言之る。表 6 の 結果より，勾配法による対応点の選定が最も有効であ るのは，視差の影響が強くなる画像（室内や交差点の シーン）を対象とした場合であると考えられる。縦視 差検定時の標定要素の推定（モデルの作成）において, 対応点の標本として対応の確度の高いものを選定する という目的に対し, 同手法の有効性を確認古ることが 出来たと考えられる。

\section{（3）対応点の算出結果について}

全ての処理画像に対して, 良好な対応点の算出結果
を得ることが出来た（図 5 〜図10)。表 6 の RMSE 結 果より精度的にも極めて高精度な対応が取得されてい ることが確認出来る。対応点数については, 視差の影 響の小さな画像ほど多数の対応点が取得される傾向に ある。

\section{(4) 処理パラメータについて}

今回の実験では，取得可能な対応点の数を多くする ために，確率的弛緩法に拈ける提案手法の拘束条件に 関するパラメー夕を弱めに設定した。その結果, 確率 的弛緩法適用時における䛊対応の発生率がやや大きく なっているが，その後の処理で誤対応が着実に棄却さ れていく様子が表 6 より確認出来る。適用実験では, 
全ての処理画像に対して同一のパラメータを用いたに もかかわらず，ほぼ完全に妥当な対応結果を算出する ことが出来た。提案手法の処理画像の違いに対する安 定性が確認されたものと考えられる。

\section{4.まとめ}

撮影対象の異なる様々な画像に対して，ロバストな 対応点取得を目的とした自動処理アルゴリズムを提案 し，実画像による検証実験を行った。確率的弛緩法に 対して，援用点による拘束条件を設定することで，対 応付けの精度を飛躍的に向上させることが可能である ことが明らかとなった。また，対応点抽出において勾 配法を併用することで, 確率的弛緩法の結果からより 確度の高い対応を選び出すことが可能なことも分かっ た。可変 LQS 法を利用した視差方程式により最終的 な対応の検定を行うことで，極めて高精度な対応点抽 出が可能となることも実験によって確認された。これ らの手法の複合的な使用によって，処理のロバスト性 が高められるため, 個々の処理のパラメー夕設定を比 較的緩くすることが可能となり，その結果各種処理画 像への依存度の小さい安定した相互標定の自動処理を 実現することが可能となった。

\section{5 . 今後の課題}

対応点の算出結果を見ると, 撮影地点に接近するに 従って視差の影響が増大するような画像（交差点や造 成地のシーン）では，そのような領域から対応点が取 得出来ていないことが分かる。これは視差の影響が強 くなると, 対応点間の幾何学的な位置関係が大きく変 化する結果, 確率的弛緩法による対応付けがうまく行 われないためである。より安定な相互標定モデルを構 築するには，画像全体から対応点を取得する必要性が あることから，今後はこのような領域からも対応点を 取得可能とするような工夫が必要である。一方で，標 定処理と depth map 作成処理の一元化というような ことも視野に入れながら，今後も検討を続けていきた いと考えている。

（受付日1998.7.16，受理日1998.9.14）

\section{参考文献}

1) L. Tang and C. Heipke, "Automatic Relative Orientation of Aerial Images", PHOTOGRAMMETRIC ENGINEERING \& REMOTE SENSING, vol. LXII, No. 1, pp.47-55, 1996.

2 ) L. Tang, J. Braun, R. Debitsch, “Automatic aerotriangulation-concept, realization and results", PHOTOGRAMMETRY \& REMOTE SENSING, vol. 52, No. 3, pp.122-131, 1997.

3 ）高木幹雄, 鳥脇純一郎, 田村秀行 編, “画像処理 アルゴリズムの最新動向”, (株)新技術コミュニケー ションズ, pp.108-144, 1986。

4 ）高木幹雄, 下田陽久 監修, “画像解析ハンドブッ ク”, 東京大学出版会, pp.707-722, 1991。

5 ）画像処理ハンドブック編集委員会, “画像処理ハン ドブック”，(株)昭晃堂, pp.249-250, pp.304-306, 1987 。

6 ）大田友一, 山田博三, “動的計画法によるパターン マッチング”, 情報処理, Vol. 30, No. 9, pp 1058-1066, 1989。

7 ）大田友一, 金出武雄, “走查線間の整合性を考慮し た 2 段の動的計画法によるステレオ対応探索”, 情報 処理, Vol. 26, No. 11, pp.1356-1363，1985。

8 ）動体計測研究会 編, “イメージセンシング”, (社) 日本測量協会, pp.96-97，1997。

9 ）野口卓, 奥富正敏, “ステレオ画像を用いた道路領 域の抽出”, 第 4 回画像センシングシンポジウム講演 論文集, 画像センシング技術研究会, pp.73-78, 1998。

10) S. M. Smith and J. M. Brady, "SUSAN-A New Approach to Low Level Image Processing”, Int. Journal of Computer Vision, vol. 23, No. 1, pp.45 $-78,1997$.

11) P. J. Rousseeuw and A. M. Leroy, "Robust Regression and Outlier Detection", John Wiley \& Sons, New York, 1987.

12）(社) 日本写真測量学会·解析写真測量委員会, “解 析写真測量 改訂版”, (社) 日本写真測量学会, pp. $66-70,1997$ 。 